\title{
HISTORY AND TENDENCIES IN DEVELOPMENT OF THE INTERNATIONAL ATHLETIC TOURNAMENT "NEW STARS IN ATHLETICS"
}

\author{
Grigor Gutev
}

National Sports Academy „Vassil Levski”, Bulgaria

\begin{abstract}
Analyzing history can help us manage the future of athletic tournaments, improve them and make them more interesting and dynamic. For this purpose, we analyze the one of the oldest Bulgarian athletic tournaments and compared it to the world elite for the corresponding year, so we can bring out information regarding most popular disciplines and their level. The period covered by our analysis is 11 years (2009-2019). A detailed comment is made both on each discipline, group of discipline and results divided by gender. We examined sport results from the tournament and the world elite for the period of the study and compared them by results (seconds, minutes, meters) and by applying the result from IAAF scoring tables.
\end{abstract}

Key words: development, tournament, history, athletics

\section{INTRODUCTION}

Athletics tournaments are inseparable part of each national athletic association sport calendar. The oldest and still organized outdoor tournament in Bulgaria (part of Bulgarian Athletic Federation sport calendar) is "New Stars in athletics". This fact provokes our interest to analyze it.

The athletic tournament, first called "Yordanka Nikolova" was started in 1979 by lecturers from Department "Track \& Field" (NSA "Vasil Levski”), as a competition for students. After that the competition was named "New Stars in Athletics" (NSA) and became one of the pillars of modern Bulgarian athletics sport calendar (organized as tradition in the month of May). (Stoykov et al., 2006)

\section{Aim and objectives of the study}

The aim of the study is to trace and analyze "New Stars in athletics" tournament main disciplines and sport result level compared to the world elite.

As objectives of the study we analyze the last 11 years (2009-2019) of the tournament (so-called modern history) to find the most traditional disciplines for men and women in the program of the tournament. We examined sport results from the tournament and the world elite for the period of the study and compared them by results (seconds, minutes, meters) and by applying the result from IAAF scoring tables. (Spiriev et al., 2014). Similar approachec were used in the study of Kr. Gutev (2008) and I. Dimova (2019), but different disciplines in athletics - hurdle running and heptathlon.

\section{METHODS}

A historical analysis of sport result data was the main method used for collecting sport results for the period of the study.

For the purpose of the study we use several statistical methods: descriptive statistics methods, variance analysis and frequency analysis.

The comparison was made using the best result in each studied discipline and the world best (leading) result of the same discipline for the year.

\section{RESULTS}

After applying the frequency analysis for all disciplines included in the tournament program for the studied period (2009-2019) we present the most common, we could say the traditional disciplines, for the tournament on Figure 1 (for men) and Figure 2 (for women). The disciplines are divided in three main groups: running, jumping and throwing disciplines. 


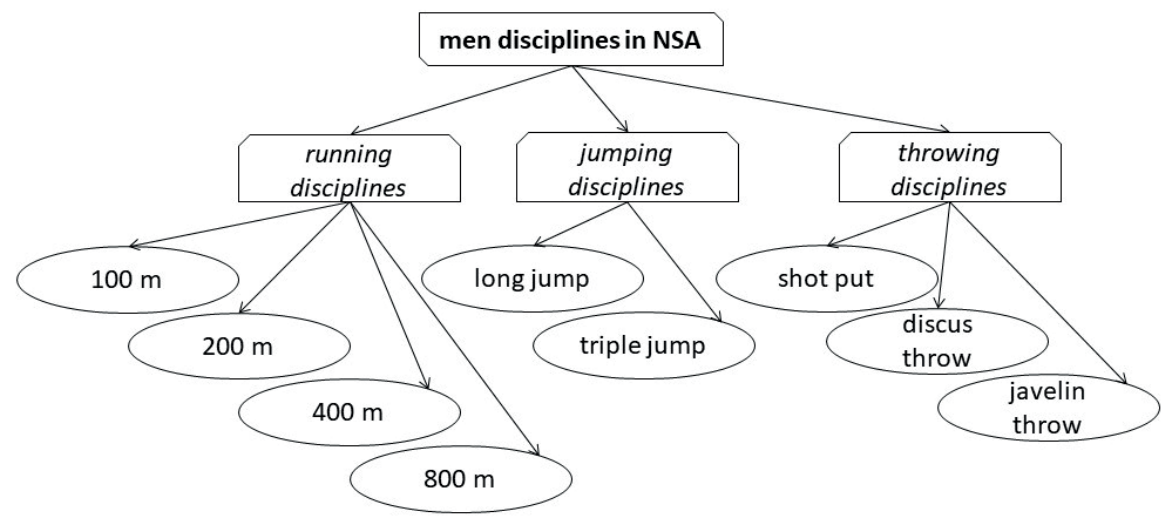

Figure 1. Most common disciplines in the program of NSA tournament for the period 2009-2019 - men.

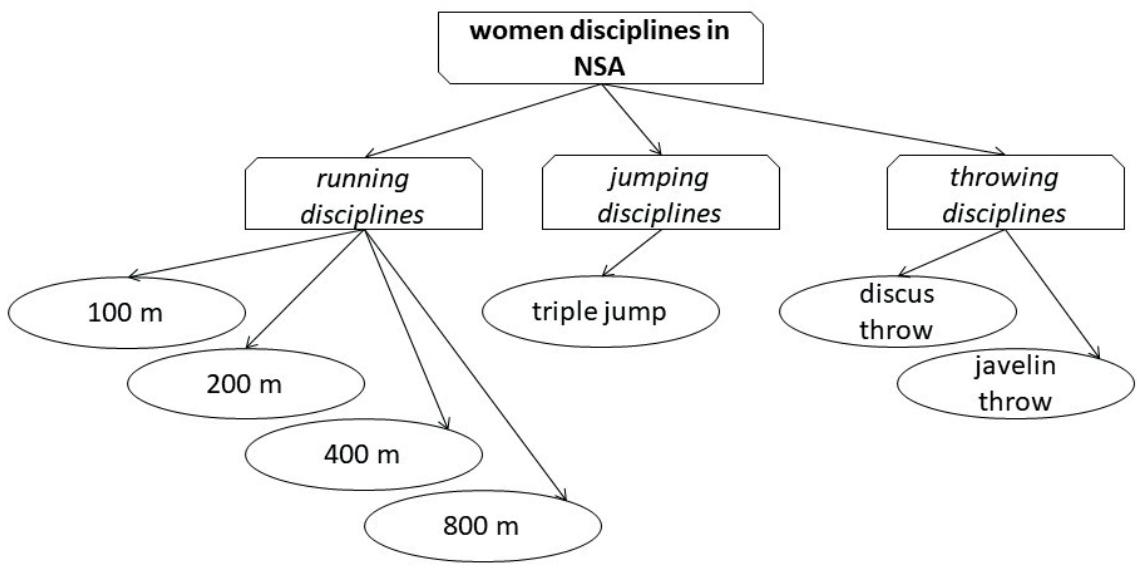

Figure 2. Most common disciplines in the program of NSA tournament for the period 2009-2019 - women.

On Table 2 we see information regarding the num- in the running events, compared to the jump and ber of participants in NSA (average, minimum throw events. Also, we can note larger number of and maximum number of athletes). Both for men participants in men group, compared to women. and women we find bigger number of participants

Table 1. Number of participants in the main events of the NSA tournament for the studied period.

\begin{tabular}{|c|c|c|c|c|c|c|c|c|c|c|}
\hline \multirow{2}{*}{\multicolumn{2}{|c|}{$\begin{array}{c}\text { DISCIPLINE } \\
\text { GROUPS MEN } \\
\text { DISCIPLINE }\end{array}$}} & \multicolumn{4}{|c|}{ RUNNING DISCIPLINES } & \multicolumn{2}{|c|}{$\begin{array}{c}\text { JUMP } \\
\text { DISCIPLINES }\end{array}$} & \multicolumn{3}{|c|}{$\begin{array}{l}\text { THROWING } \\
\text { DISCIPLINES }\end{array}$} \\
\hline & & 100 & 200 & 400 & 800 & LJ & TJ & SP & DT & JT \\
\hline \multirow{3}{*}{ छี } & avg participants & 25 & 20 & 21 & 12 & 8 & 5 & 8 & 7 & 7 \\
\hline & max participants & 40 & 29 & 26 & 16 & 13 & 10 & 12 & 9 & 10 \\
\hline & min participants & 12 & 13 & 16 & 6 & 6 & 2 & 3 & 4 & 5 \\
\hline \multicolumn{2}{|c|}{$\begin{array}{c}\text { DISCIPLINE } \\
\text { GROUPS WOMEN }\end{array}$} & \multicolumn{4}{|c|}{ RUNNING DISCIPLINES } & \multicolumn{2}{|c|}{$\begin{array}{c}\text { JUMP } \\
\text { DISCIPLINES }\end{array}$} & \multicolumn{3}{|c|}{$\begin{array}{l}\text { THROWING } \\
\text { DISCIPLINES }\end{array}$} \\
\hline \multicolumn{2}{|c|}{ DISCIPLINE } & 100 & 200 & 400 & 800 & & TJ & & DT & $\mathrm{JT}$ \\
\hline \multirow{3}{*}{$\begin{array}{l}\text { चี } \\
\text { च } \\
\vdots\end{array}$} & avg participants & 13 & 14 & 9 & 9 & & 5 & & 6 & 6 \\
\hline & max participants & 20 & 24 & 13 & 14 & & 11 & & 8 & 11 \\
\hline & min participants & 5 & 5 & 3 & 3 & & 2 & & 5 & 2 \\
\hline
\end{tabular}

For better insight, we present results comparison list on Table 2. between NSA tournament and World leading rank 
Table 2. Results (average, best and weakest) from tournament and world leading rank list.

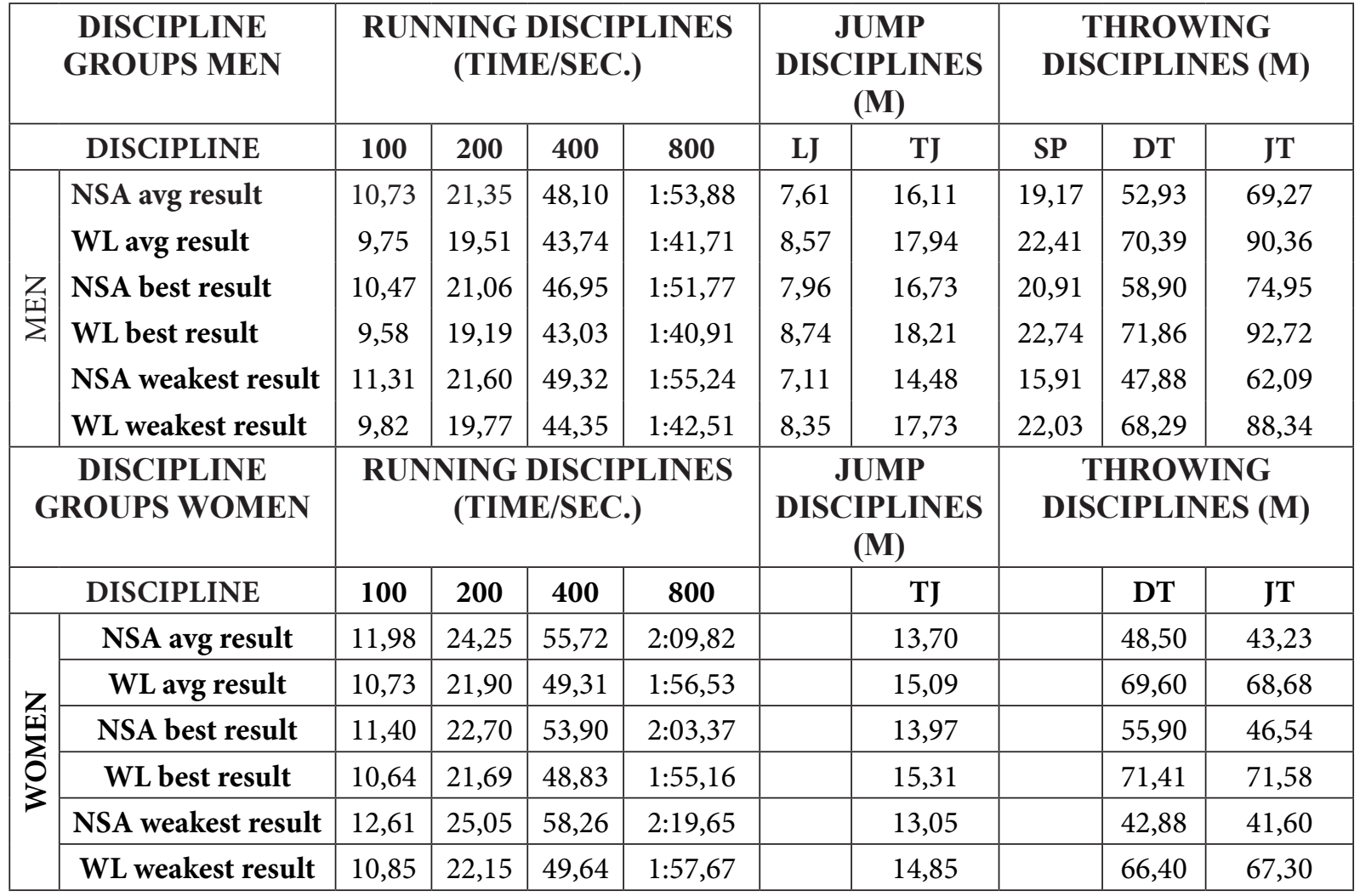

It is hard to compared different disciplines using and women to evaluate sport results in the different only sport result measured in seconds, minutes or disciplines (the ones from the tournament and the meters. So, we use the IAAF scoring tables for men world elite rank list) - Table 3.

Table 3. Results (average, best and weakest)

from tournament and world leading rank list presented in points.

\begin{tabular}{|c|c|c|c|c|c|c|c|c|c|c|}
\hline \multirow{2}{*}{\multicolumn{2}{|c|}{$\begin{array}{c}\begin{array}{c}\text { DISCIPLINE GROUPS MEN } \\
\text { (RESULT }=\text { POINTS) }\end{array} \\
\text { DISCIPLINE }\end{array}$}} & \multicolumn{4}{|c|}{$\begin{array}{c}\text { RUNNING } \\
\text { DISCIPLINES }\end{array}$} & \multicolumn{2}{|c|}{$\begin{array}{c}\text { JUMP } \\
\text { DISCIPLINES }\end{array}$} & \multicolumn{3}{|c|}{$\begin{array}{l}\text { THROWING } \\
\text { DISCIPLINES }\end{array}$} \\
\hline & & 100 & 200 & 400 & 800 & LJ & $\mathrm{TJ}$ & SP & DT & $\mathrm{JT}$ \\
\hline \multirow{6}{*}{$\sum_{i=1}^{Z}$} & NSA avg result & 970 & 1016 & 975 & 919 & 1053 & 1070 & 1067 & 931 & 942 \\
\hline & WL avg result & 1294 & 1298 & 1269 & 1276 & 1262 & 1265 & 1265 & 1252 & 1240 \\
\hline & NSA best result & 1050 & 1059 & 1048 & 976 & 1129 & 1136 & 1175 & 1040 & 1022 \\
\hline & WL best result & 1356 & 1351 & 1321 & 1301 & 1300 & 1294 & 1285 & 1279 & 1273 \\
\hline & NSA weakest result & 797 & 981 & 899 & 882 & 946 & 899 & 835 & 838 & 841 \\
\hline & WL weakest result & 1269 & 1256 & 1225 & 1251 & 1214 & 1243 & 1242 & 1213 & 1211 \\
\hline \multicolumn{2}{|c|}{$\begin{array}{c}\text { DISCIPLINE GROUPS } \\
\text { WOMEN (RESULT=POINTS) }\end{array}$} & \multicolumn{4}{|c|}{$\begin{array}{c}\text { RUNNING } \\
\text { DISCIPLINES }\end{array}$} & \multicolumn{2}{|c|}{$\begin{array}{c}\text { JUMP } \\
\text { DISCIPLINES }\end{array}$} & \multicolumn{3}{|c|}{$\begin{array}{l}\text { THROWING } \\
\text { DISCIPLINES }\end{array}$} \\
\hline & DISCIPLINE & 100 & 200 & 400 & 800 & & TJ & & DT & $\mathrm{JT}$ \\
\hline \multirow{6}{*}{$\sum_{0}^{Z}$} & NSA avg result & 996 & 1013 & 987 & 987 & & 1072 & & 860 & 754 \\
\hline & WL avg result & 1259 & 1248 & 1233 & 1225 & & 1230 & & 1249 & 1239 \\
\hline & NSA best result & 1114 & 1165 & 1054 & 1094 & & 1099 & & 996 & 813 \\
\hline & WL best result & 1280 & 1271 & 1253 & 1250 & & 1252 & & 1282 & 1293 \\
\hline & NSA weakest result & 874 & 937 & 896 & 831 & & 1006 & & 757 & 724 \\
\hline & WL weakest result & 1233 & 1222 & 1220 & 1204 & & 1205 & & 1189 & 1213 \\
\hline
\end{tabular}

For enrichment of the analysis we analyze the dif- ference between NSA tournament best result and 
World Leading rank list in sport result and points, similar level.

presented on Table 4. For men events the average Summarized, the best discipline as sport result, gap of result from NSA and world elite vary be- part of the tournament for women is the triple tween 195 (for Long jump) and 357 points (for 800 jump, followed by the sprint events $(100 \mathrm{~m}$, $\mathrm{m})$. Closest to the word elite were the results from $200 \mathrm{~m}$ and $400 \mathrm{~m}$ ). The women javelin discithe tournament for men were Long jump, Shot put pline is undoubtedly the weakest in the athletand Triple jump. All other events for men are on ics program.

Table 4. Differences between NSA results and World Leading rank list in sport result and points.

\begin{tabular}{|c|c|c|c|c|c|c|c|c|c|c|}
\hline \multirow{2}{*}{\multicolumn{2}{|c|}{\begin{tabular}{|c} 
DISCIPLINE GROUPS \\
MEN \\
DISCIPLINE \\
\end{tabular}}} & \multicolumn{4}{|c|}{ RUNNING DISCIPLINES } & \multicolumn{2}{|c|}{\begin{tabular}{|c|} 
JUMP \\
DISCIPLINES \\
\end{tabular}} & \multicolumn{3}{|c|}{$\begin{array}{l}\text { THROWING } \\
\text { DISCIPLINES }\end{array}$} \\
\hline & & 100 & 200 & 400 & 800 & LJ & TJ & SP & DT & JT \\
\hline \multirow{6}{*}{$\sum_{i=1}^{Z}$} & $\begin{array}{l}\text { avg difference between } \\
\text { NSA and WL result }\end{array}$ & 0,98 & 1,84 & 2,20 & $0: 12,17$ & 0,96 & 1,83 & 3,24 & 17,46 & 21,08 \\
\hline & $\begin{array}{l}\text { avg difference between } \\
\text { NSA and WL result } \\
\text { (points) }\end{array}$ & 325 & 282 & 294 & 357 & 209 & 195 & 198 & 321 & 298 \\
\hline & $\begin{array}{l}\text { smallest difference } \\
\text { between NSA and } \\
\text { WL result }\end{array}$ & 0,67 & 1,38 & 2,20 & $0: 09,26$ & 0,40 & 1,00 & 1,12 & 10,60 & 16,33 \\
\hline & $\begin{array}{l}\text { smallest difference } \\
\text { between NSA and } \\
\text { WL result (points) }\end{array}$ & 226 & 212 & 193 & 275 & 87 & 107 & 67 & 195 & 231 \\
\hline & $\begin{array}{l}\text { largest difference } \\
\text { between NSA } \\
\text { and WL result }\end{array}$ & 0,98 & 1,84 & 2,20 & $0: 12,17$ & 0,96 & 1,83 & 3,24 & 17,46 & 21,08 \\
\hline & $\begin{array}{l}\text { largest difference be- } \\
\text { tween NSA and } \\
\text { WL results (points) }\end{array}$ & 540 & 340 & 387 & 416 & 341 & 395 & 450 & 430 & 432 \\
\hline & $\begin{array}{c}\text { DISCIPLINE } \\
\text { GROUPS WOMEN } \\
\text { (RESULT=POINTS) }\end{array}$ & \multicolumn{4}{|c|}{ RUNNING DISCIPLINES } & \multicolumn{2}{|c|}{\begin{tabular}{|c|} 
JUMP \\
DISCIPLINES
\end{tabular}} & \multicolumn{3}{|c|}{$\begin{array}{l}\text { THROWING } \\
\text { DISCIPLINES }\end{array}$} \\
\hline & DISCIPLINE & 100 & 200 & 400 & 800 & LJ & TJ & SP & DT & JT \\
\hline \multirow{6}{*}{ 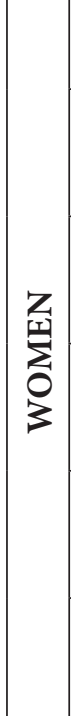 } & $\begin{array}{l}\text { avg difference between } \\
\text { NSA and WL result }\end{array}$ & 1,25 & 2,35 & 6,41 & $0: 13,28$ & & 1,39 & & 21,10 & 25,45 \\
\hline & $\begin{array}{l}\text { avg difference between } \\
\text { NSA and WL result } \\
\text { (points) }\end{array}$ & 263 & 235 & 246 & 238 & & 158 & & 389 & 486 \\
\hline & $\begin{array}{l}\text { smallest difference be- } \\
\text { tween NSA and } \\
\text { WL result }\end{array}$ & 0,60 & 0,72 & 4,46 & $0: 06,78$ & & 1,02 & & 10,50 & 21,15 \\
\hline & $\begin{array}{l}\text { smallest difference be- } \\
\text { tween NSA and } \\
\text { WL result (points) }\end{array}$ & 130 & 75 & 174 & 130 & & 120 & & 193 & 408 \\
\hline & $\begin{array}{l}\text { largest difference } \\
\text { between NSA and WL } \\
\text { result }\end{array}$ & 1,91 & 3,27 & 9,29 & $0: 23,30$ & & 2,26 & & 26,08 & 29,98 \\
\hline & $\begin{array}{l}\text { largest difference be- } \\
\text { tween NSA and } \\
\text { WL results (points) }\end{array}$ & 392 & 324 & 351 & 397 & & 246 & & 480 & 569 \\
\hline
\end{tabular}




\section{DISCUSSION}

All the data above gave information regarding the different events, but the question men or women disciplines are on better level in the NSA tournament stayed open. So, we present summarized data (results are analyzed in points) on Table 5 . Women disciplines reach better average level for the studied and best results (158 points difference between NSA and world elite). But we also find weaker result, compared to men, in the studied period for women events part of the tournament. Men events come with more stable sport results.

Table 5. Combined level of men and women disciplines for the studied period (2009-2019).

\begin{tabular}{|c|c|c|c|c|}
\hline & & $\begin{array}{c}\text { average for the pe- } \\
\text { riod 2009-2019 }\end{array}$ & $\begin{array}{c}\text { best for the period } \\
2009-2019\end{array}$ & $\begin{array}{c}\text { worst for the pe- } \\
\text { riod 2009-2019 }\end{array}$ \\
\hline MEN & $\begin{array}{c}\text { avg difference between NSA } \\
\text { and WL result (points) }\end{array}$ & 275 & 195 & 357 \\
\hline WOMEN & $\begin{array}{c}\text { avg difference between NSA } \\
\text { and WL result (points) }\end{array}$ & 288 & 158 & 486 \\
\hline
\end{tabular}

Also, based on the number of participants and results from the studied period we can concluded that running events were on higher level, compared to jumping and throwing events.

\section{REFERENCES}

Dimova, I. (2019). Sustoyanie i tendencii v razvitieto na suvremennia sedmoboi za jeni v Bulgaria, „Mejdunarodna nauchna konferencia na Katedra „Leka Atletika“ 2019, sp. „Leka Atletika i Nauka“. br. 1 (19), Sofia.

Gutev, Kr. (2008). Sravnitelen analiz na postignati rezultati $\mathrm{v}$ disciplinata $60 \mathrm{~m}$ prepiatstveno biagene - jeni, ot DIP v zala - 2008 g., sp. „Leka atletika i Nauka“, br. 1(8).
Spiriev, B., A. Spiriev. (2014). IAAF Scoring tables of athletics. Multiprint-Monaco, IAAF, 2014.

Stoykov, St., Ap. Slavchev, S. Popova, D. Sholeva. (2006). 60 godini Katedra „Leka atletika“. IK „Tip-top pres“, Sofia, ISBN-10: 954-8964-78-3.

Corresponding author:

Grigor Gutev, PhD

Department "Track \& Field"

National Sports Academy "Vassil Levski", Studentski grad, 1700

Bulgaria, Sofia,

E-mail: grigor.gutev@gmail.com 